\title{
PERKAWINAN NGUBENG \\ DI DESA PAKRAMAN PENATARAN DESA MUNDEH KAUH KECAMATAN SELEMADEG BARAT KABUPATEN TABANAN
}

\author{
Desak Nyoman Seniwati \\ Ni Gusti Ayu Putu Artaningsih \\ Fakultas Ilmu Agama, Seni dan Budaya \\ desakseniwati1960@gmail.com
}

\begin{abstract}
ABSTRAK
Artikel ini membahas tentang Perkawinan Ngubeng di Desa Pakraman Penataran. Poin yang diangkat adalah proses perkawinan ngubeng, bentuk dan sarana upakara yang digunakan. Penelitian ini menggunakan metode kualitatif dengan teknik pengumpulan data terdiri dari observasi non partisipan, wawancara tokoh adat dan agama, dan studi kepustakaan. Berdasarkan itu, didapatkan penjelasan yakni perkawinan Ngubeng dilakukan karena pihak perempuan tidak mendapat restu dari kedua orang tua, sehingga perkawinan tetap dilaksanakan dengan perwalian adat saja. Proses pelaksanaan Perkawinan Ngubeng di Desa Pakraman Penataran adalah sebagai berikut : 1) Mapadik, yaitu acara awal perkawinan dimana keluarga pihak laki-laki (purusa) mengambil inisiatif meminta si gadis, untuk dikawinkan dengan anak prianya. 2) Setelah mendapat jawaban disetujui atau tidak, seperti terjadinya perkawinan ngubeng yang sudah jelas tidak ada persetujuan dari pihak orang tua si gadis, maka tindakan yang dilakukan adalah melarikan anak gadisnya tanpa sepengetahuan orang tuanya. 3) Prosesi upacara yang dilaksanakan di rumah mempelai pria diantaranya natab banten byakala, pakala-kalaan, dan pejati 4). Ngandeg, yaitu memberitahukan kepada keluarga wanita bahwa anak gadisnya telah kawin, sebagai tanda bukti biasanya ada surat keterangan dari si wanita bahwa ia kawin berdasarkan saling mencintai, tanpa ada unsur paksaan.
\end{abstract}

Kata Kunci: Perkawinan, Ngubeng, Desa Pakraman Mundeh

\section{ABSTRACT}

This article discusses the Ngubeng Marriage in Pakraman Penataran Village. The point raised is the wedding process of ngubeng, the form and means of ceremonies used. This study uses qualitative methods with data collection techniques consisting of nonparticipant observation, interviews with traditional and religious leaders, and literature studies. Based on that, an explanation was obtained that the Ngubeng marriage was carried out because the women did not get the blessing of both parents, so the marriage was still carried out with customary guardianship. The process of implementing the Ngubeng Marriage in Pakraman Penataran Village is as follows: 1) Mapadik, which is the 
initial marriage ceremony where the family of the male (purusa) takes the initiative to ask the girl, to be married to her male child. 2) After getting an answer approved or not, such as the marriage of ngubeng where there is clearly no agreement from the girl's parents, then the action taken is to run away his daughter without the knowledge of her parents. 3) The procession of the ceremony which is held at the groom's house including natab banten byakala, pakala-kalaan, and pejati 4). Ngandeg, which tells the woman's family that her daughter has married, as proof that usually there is a statement from the woman that she married based on mutual love, without any compulsion.

Keywords: Marriage, Ngubeng, Pakraman Mundeh Village

\section{PENDAHULUAN}

Undang-Undang Nomor 1 Tahun 1974, pasal 1 menyatakan bahwa perkawinan adalah ikatan lahir batin antara seorang pria dengan seorang wanita sebagai suami istri dengan tujuan membentuk rumah tangga (keluarga) yang bahagia dan kekal berdasarkan Ketuhanan Yang Maha Esa. Bunyi pasal tersebut di atas dapat dilihat beberapa unsur yang menggambarkan sifat perkawinan seperti adanya ikatan lahir batin antara seorang pria dengan wanita, ikatan tersebut adalah ikatan sebagai suami istri, dengan tujuan membentuk keluarga (rumah tangga), dan atas dasar Ketuhanan Yang Maha Esa (Gelgel, 2006:80).

Perkawinan adalah merupakan ikatan lahir bathin antara suami dan istri, dengan landasan saling kasih-mengasihi, bantu membantu serta membagi suka dan duka (Artayasa, dkk, 1998:2). Ikatan lahir maupun bathin antara seorang pria dengan seorang wanita hendaknya mendapat ijin dari kedua belah pihak, yaitu kedua orang tuanya. Di samping itu, menurut pasal diatas, perkawinan tidak dibenarkan melakukan unsur paksaan atau tekanan-tekanan dari pihak lain, hal ini untuk menghindari keretakan hubungan suami istri dalam mengarungi bahtera rumah tangganya.

Menurut Koentjaraningrat dalam bukunya Manusia dan Kebudayaan di Indonesia menyatakan : Perkawinan adalah suatu saat yang sangat penting dalam kehidupan masyarakat di Bali, karena dengan itu dianggap sebagai warga penuh dari masyarakat dan baru sesudah itu dia memperoleh hak-hak dan kewajiban sebagai warga kelompok kerabat (Koentjaraningrat, 1979:294).

Menurut Murtika dalam bukunya Azas-Azas Perkawinan di Indonesia berpendapat bahwa perkawinan adalah suatu ikatan yang sah untuk membina rumah tangga dan keluarga sejahtera, bahagia, dimana suami-istri memikul amanah dan tanggung jawab oleh karenanya akan mengalami suatu proses sosiologis yang berat yaitu kehamilan dan kelahiran yang meminta pengorbanan (Murtika, 1987:2).

Selanjutnya menurut HS. Habib Adnan dalam bukunya Pokok-Pokok Ajaran Agama Hindu mengatakan perkawinan adalah merupakan jenjang memasuki institusi keluarga memiliki otonomi sendiri, artinya keluarga merupakan inti masyarakat, sekaligus gambaran sebuah komunitas yang memiliki kewenangan sendiri (Adnan, 1999:224).

Berdasarkan kutipan-kutipan di atas maka pengertian perkawinan adalah ikatan lahir bathin antara seorang pria dengan seorang wanita, yang dilandasi rasa saling kasihmengasihi , cinta mencintai dan penuh rasa tanggung jawab dalam tujuan yang sama untuk membina rumah tangga sejahtera, bahagia dan kekal dengan saksi sekala dan niskala (niskala yaitu Tuhan Yang Maha Esa). 
Terjadinya ikatan lahir dan bathin, menyebabkan seseorang terbatas, baik fisik maupun bathinnya. Ia dibatasi oleh norma-norma yang berlaku dalam keluarga tersebut. Bagi mereka yang telah menjalin perkawinan, tinggal bersama adalah baik. Sebab itu adalah salah satu wujud persatuan fisik. Begitu pula seia-sekata dalam penentuan sesuatu, merupakan keharusan bagi mereka yang telah menggalang perkawinan. Keadaan demikian adalah cermin adanya penyatuan bathin.

Kenyataan yang terjadi dalam kehidupan ini sebaliknya, perkawinan itu hanya dianggap sebagai pemuas nafsu seksual, terbukti masih banyak terjadi kasus kawin cerai, kawin paksa, pemerkosaan dan lain sebagainya. Ajaran agama memandang perkawinan itu adalah sebagai suatu hal yang suci. Beberapa kitab suci agama Hindu juga terdapat uraian tentang pengertian perkawinan. Istilah perkawinan dalam kitab suci dan susastra Hindu terkenal dengan istilah Wiwaha. Kitab Manawa Dharmaçastra II.67 menyebutkan bahwa :

Anenopanayare 'piprātewicemāha
Waiwāhiko widhih strinām
Samskāro waidikah smirtah,
Patisewā gurau wāso
Gāhartho 'gni parikriya

Terjemahannya :

Bagi wanita upacara perkawinan dinyatakan merupakan samskara menurut Veda yang mulainya sama dengan upacara inisiasi, melayani suami sama dengan berdiam di asrama guru dan kewajiban-kewajiban rumah tangga sama dengan pemujaan sahari-haripada api suci (Pudja, Sudharta, 1995:80).

Berdasarkan kutipan sloka di atas perkawinan (wiwaha) adalah suatu samskara yang merupakan salah satu bagian dari banyaknya samskara sejak dalam kandungan, kelahiran, sampai pada upacara kematian. Perkawinan juga merupakan yadnya, sehingga umat Hindu memandang perkawinan itu sebagai suatu hal yang suci.

Pelaksanaan suatu perkawinan, sudah pasti memakai cara-cara atau sistem perkawinan. Sistem perkawinan adalah cara atau bentuk usaha yang ditempuh oleh seseorang dalam melangsungkan perkawinan. Berdasarkan tradisi dan adat yang berlaku di Bali dikenal 4 (empat) sistem perkawinan antara lain : (1). Sistem meminang (mepadik) yaitu perkawinan yang terjadi, didahului dengan proses persetujuan antara keluarga dari kedua mempelai. Dalam hal ini pihak keluarga laki terlebih dahilu mohon restu kepada pihak keluarga perempuan agar menyetujui anak gadisnya dikawini oleh mempelai lakilaki. (2). Sistem ngerangkat (ngerorod) yaitu perkawinan yang terjadi tanpa didahului dengan persetujuan keluarga kedua belah pihak. Terjadinya perkawinan ini merupakan kehendak kedua mempelai yang berlandaskan cinta sama cinta, dan ingin melaksanakan perkawinan. (3). Sistem nyentana (matrilokal), sistem ini hamper mirip dengan sistem meminang, hanya saja inisiatif untuk memohon berasal dari keluarga perempuan. Hal ini dilakukan karena pihak perempuan tidak memiliki saudara laki. Di lain pihak ada kekhawatiran kalau-kalau keluarganya mengalami kepunahan, oleh sebab itu, salah satu dari anaknya diangkat statusnya menjadi purusa. Selanjutnya jika datang masanya, ia akan dimohonkan suami oleh keluarganya, sebagaimana sistem seorang pria memohon seorang istri. (4). Sistem Melegandang yaitu suatu bentuk perkawinan yang dilakukan dengan jalan kekerasan (paksaan) kepada seorang wanita. Tentu perkawinan ini tidak dilandasi oleh adanya "cinta sama cinta" (Tim, 2007: 24) 
Sesuai dengan adat dan tradisi, masing-masing daerah yang ada di Bali memiliki perbedaan-perbedaan dalam penerapan sistem perkawinan. Antara dearah satu dengan daerah lain tidak mungkin sama persis tata pelaksanaan suatu perkawinan. Seperti contoh pelaksanaan tata cara perkawinan di Singaraja belum tentu persis sama dengan tata cara pelaksanaan perkawinan yang ada di Tabanan.

Fenomena ini terjadi di Desa Pakraman Penataran, Desa Mundeh Kauh, Kecamatan Selemadeg Barat, Kabupaten Tabanan. Tadisi yang dimiliki di daerah ini sedikit berbeda dengan tempat lain di Bali. Salah satunya tradisi atau sistem perkawinan yang sering disebut Perkawinan Ngubeng. Perkawinan ini dilaksanakan karena dilandasi adanya suatu kendala yakni karena tidak mendapat persetujuan dari pihak orang tua mempelai wanita. Sistem perkawinan ini termasuk ke dalam sistem perkawinan ngerangkat (ngerorod) perbedaannya terdapat pada tata cara pelaksanaannya, yaitu : Mapadik, acara awal perkawinan dimana keluarga pihak laki-laki (purusa) mengambil inisiatif meminta si gadis, untuk dikawinkan dengan anak prianya. Setelah mendapat jawaban disetujui atau tidak, seperti terjadinya perkawinan ngubeng yang sudah jelas tidak ada persetujuan dari pihak orang tua si gadis, maka tindakan yang dilakukan adalah melarikan anak gadisnya tanpa sepengetahuan orang tuanya. Proses upacara yang dilaksanakan di rumah mempelai pria diantaranya natab banten byakala, pakala-kalaan, pejati. Kemudian dilanjutkan dengan upacara mepamit bagi mempelai wanita dari sanggah kemulan si pria. Disinilah ciri khas dari pelaksanaan upacara perkawinan ngubeng itu tampak, karena si wanita tidak datang lagi ke rumahnya untuk mepamit secara niskala.

Bertolak dari uraian di atas, maka sangat penting untuk diketahui lebih jelas tentang pelaksanaan upacara perkawinan ngubeng tersebut. Sehingga peneliti tertarik untuk mengadakan penelitian ini.

\section{METODE}

Dalam pengumpulan data dalam penelitian ini, penulis menggunakan metode observasi non partisipan, teknik wawancara mendalam dengan narasumber yang relevan, dan melakukan penelusuran berkaitan dengan pustaka-pustaka yang berhubungan secara langsung dengan penelitian ini.

\section{PEMBAHASAN}

\subsection{Perkawinan Ngubeng di Desa Pakraman Penataran.}

Proses awal perkawinan adalah simpati. Perasaan simpati mendorong orang untuk saling mengenal. Pengenalan yang mendalam mewujudkan rasa saling mencintai. Kecintaan itu memungkinkan orang untuk menjalin perkawinan. Menurut mitologi Semaradahana, rasa cinta (tarik-menarik) adalah "kodrat". Hal ini merupakan wujud nyata hidupnya Sang Hyang Semara-Ratih dalam lubuk hati manusia (Natih, dkk, 1987:2).

Kitab Manawa Dharmaçastra IX sloka 96 menyebutkan :

Prajanārtha striyā̄ s'aūtāh

Samtānarthā $\div$ ca manāwāh,

Tasmāt sādāróo dharma

Çrutau patnya saháditáa 
Terjemahannya :

Untuk menjadi ibu, wanita diciptakan dan untuk menjadi ayah, laki-laki diciptakannya. Karena itu ditetapkan dalam Veda untuk dilaksanakan oleh suami (pria) bersama dengan istri (wanita). (Pudja, Sudharta,1995:551).

Berdasarkan sloka di atas ternyata, manusia adalah ciptaan Tuhan. Ia diciptakan dengan jenis kelaminnya, dan masing-masing jenis kelamin memiliki peran tertentu. Di samping itu, ia pun (pria dan wanita) diharapkan hidup bersama. Dari kehidupan bersama ini, memungkinkan orang untuk menjalin ikatan. Ikatan tersebut dapat bermacam-macam, salah satu diantaranya adalah perkawinan. Dalam kebersamaan dan ikatan tadi, diharapkan akan dapat menunjang kehidupannya termasuk upacara keagamaan. Di samping itu, dalam persatuannya itulah ia akan mencapai kesempurnaan. Hal tersebut ditegaskan dalam Manawa Dharmaçastra, IX sloka 45 yaitu :

Etáwánewa puruso yajjáya

Àtmá prajeti ha,

Wipráh práhustathá caitadyo

Bhartá sá småitángganá

Terjemahannya :

Ia hanya merupakan orang yang sempurna yang terdiri atas tiga orang menjai satu; istrinya, ia sendiri dan keturunannya. Demikian dinyatakan dalam Veda dan Brahmana (ahli) menyatakan dalam perumpamaannya " suami dinyatakan satu dengan istri” (Pudja, Sudharta, 1995:537).

Kehidupan manusia mengalami tingkatan kehidupan tertentu. Secara garis besarnya ada empat tingkatan yakni Brahmacari (masa hidup menuntut ilmu/berguru); Grehastha (masa hidup berumah tangga); Wanaprastha (menjauhkan diri dari keramaian dunia); dan Bhiksuka atau Sanyasin (melepaskan diri dari ikatan benda-benda duniawi).

Umumnya orang menjalani tingkatan tersebut secara teratur, dari satu tingkatan ketingkatan berikutnya. Sebagai pengecualian, ada juga yang tanpa menempuh tingkat kehidupan berumahtangga, melainkan seluruh hidupnya diabdikan untuk kepentingan ilmu pengetahuan. Belakangan ini cara tersebut amat jarang ditempuh orang. Dengan demikian, kehidupan berumahtangga adalah kodrat. Setiap orang pasti menjalaninya (Tim, 2007:30).

Menyadari akan kodrat yang demikian, pemerintah menetapkan satu hukum nasional yang mengatur segala sesuatu tentang perkawinan. Hukum tersebut dimuat dalam Undang-Undang No. 1 Tahun 1974 yang pelaksanaanya diatur dalam Peraturan Pemerintah No.9 Tahun 1975.

Berpijak pada pasal 1 Undang-Undang No. 1 Tahun 1974 menyatakan perkawinan adalah ikatan lahir batin antara seorang pria dengan seorang wanita sebagai suami istri dengan tujuan membentuk rumah tangga (keluarga) yang bahagia dan kekal berdasarkan Ketuhanan Yang Maha Esa. Rumusan ini mencerminkan adanya penyatuan dua orang pribadi (pria dan wanita) menjadi satu ikatan. Dalam perkawinan terjadi ikatan lahir dan batin. Ikatan itu menyebabkan seseorang terbatas baik fisik maupun batinnya. Ia dibatasi oleh norma-norma yang berlaku dalam keluarga tersebut. 
Berdasarkan uraian di atas perkawinan adalah kodrat. Ini berarti pelaksanaannya mesti menuruti hukum/perintah Tuhan, hal itu tidak dapat lepas dari hubungan dengan Tuhan. Ada persaksian serta permohonan restu terhadap perkawinan tersebut, atas dasar inilah perkawinan perlu pengesahan berdasarkan hukum agama (Tim, 2007:31).

Pelaksanaan suatu perkawinan tidak selalu berjalan dengan baik seperti apa yang diharapkan. Hal ini dapat disebabkan oleh berbagai faktor seperti adanya restu dari pihak keluarga, serta persaksian (Tri Upasaksi) yakni manusa saksi, bhuta saksi dan dewa saksi. Tetapi pelaksanaan perkawinan, dapat dilaksanakan walaupun salah satu pihak keluarga tidak setuju. Seperti halnya yang terjadi di Desa Pakraman Penataran, perkawinan dapat terjadi asalkan sudah ada perwalian, walaupun itu tidak dari bapak atau ibu kandung salah satu mempelai.

Perkawinan yang dilakukan seperti yang terjadi di Desa Pakraman Penataran adalah suatu perkawinan yang terjadi karena pihak perempuan tidak mendapat restu, perkawinan tetap dilaksanakan dengan perwalian adat saja, serta pelaksanaan upacara yang biasa disebut mapamit (upacara permohonan diri untuk meninggalkan keluarga secara niskala) biasanya dilaksanakan dengan jalan mempelai laki-laki mengantar mempelai perempuan kerumahnya untuk mepamit. Karena perkawinan yang terjadi tidak mendapat restu dari keluarga perempuan, maka upacara mepamit bagi mempelai wanita yang semestinya dilakukan dengan datang kerumah si wanita, dilaksanakan dari Mrajan (Sanggah Kemulan) si laki-laki. Inilah yang disebut ngubeng di dalam upacara perkawinan. Sehingga di Desa Pakraman Penataran dikenal dengan Perkawinan Ngubeng.

\subsection{Proses Pelaksanaan Upacara Perkawinan Ngubeng di Desa Pakraman Penataran}

Upacara perkawinan termasuk upacara Manusa Yadnya. Upacara ini tergolong upacara yang terbesar di antara upacara Manusa Yadnya, karena upacara ini terdiri atas beberapa tahap upacara. Dalam Buku Panca Yadnya dijelaskan tahapan upacara perkawinan secara umum terdiri atas :

1 Bila seseorang dalam melaksanakan upacara apapun, terlebih-lebih upacara perkawinan tentu diawali dengan perhitungan hari baik (ngrereh dewasa ayu).

2 Kalau perkawinan itu memang dijalankan yang sebenarnya maka pada tahap kedua ini harus dilakukan mepadik deha atau melamar si gadis.

3 Setelah Pepadikan (pinangan) selanjutnya diambil oleh calon pengantin pria.

4 Selanjutnya tahap yang keempat yaitu melaksanakan upacara Mesakapan Mewidhi Widana. Rentetan pelaksanaan upacaranya adalah sebagai berikut : mabyakala, mesakapan, ngantebang pawidhi widana pesakapan yang dipimpin oleh Pemangku atau Sang Sulinggih. Setelah upacara ini selesai kemudian perkawinan disahkan secara hukum adat dan menurut norma-norma agama oleh Pemangku Desa, Kelihan Desa, Bendesa Pakraman, dan Petugas Pemerintah seperti : Kelihan Banjar dan Perbekel.

5 Ngaturang Pejati serta sembahyang kepada Bhatara Kawitan si wanita (Tim Penyusun Pemkab Tabanan : 45-46)

Namun pelaksanaan upacara perkawinan ngubeng yang dilaksanakan di Desa Pakraman Penataran sedikit berbeda dengan pelaksanaan prosesi upacara perkawinan secara umum. Menurut Nyoman Gede Arsa, (wawancara, 8 Oktober 2017 proses pelaksanaan upacara perkawinan $n g u b e n g$ antara lain :

1 Mapadik, yaitu acara awal perkawinan dimana keluarga pihak laki-laki (purusa) mengambil inisiatif meminta si gadis, untuk dikawinkan dengan anak prianya. Ini dilakukan setelah pihak pria dan wanita sama-sama dewasa atau telah 
memenuhi persyaratan untuk melaksanakan perkawinan. Tata caranya penuh dengan basa-basi, tetapi tetap mengindahkan norma-norma adat yang berlaku di Desa Pakraman Penataran.

2 Apabila dalam tahapan mamadik (meminang) tidak mendapat persetujuan dari pihak mempelai wanita, maka kedua mempelai mengambil inisiatif untuk melakukan perkawinan ngerorod atau merangkat (kawin lari bersama-sama atas suka sama suka) guna menghindari masalah lebih lanjut. Setelah mempelai wanita diajak dan sampai di rumah mempelai laki-laki, maka dilakukan upacara perkawinan dengan prosesi ngubeng, seperti yang dilakukan di Desa Pakraman Penataran.



Mapadik di jalan (ciri khas perkawinan ngubeng)

Sumber : (Dok : Ayu Artaningsih, 10 Januari 2017)

3 Proses upacara yang dilaksanakan di rumah mempelai pria diantaranya:

a. natab banten byakala yang maknanya sebagai upacara panglukatan atau pembersihan jasmani dan rohani kedua mempelai. Menurut I Ketut Raiyasa (wawancara, 9 Oktober 2017), natab banten byakala diiringi dengan puja mantra sebagai berikut :

Om Sang Hyang Kamajaya-Kamaratih, sira ta maka uriping carmaning ngulun, yan sira angawe manusa, aja sira amiruda, amrisakiti, wehana panglukatan luputa ring lara roga, sanut sangkala, sebel kandel, ring awak sariranipun. Om siddhirastu, Om Çri çriambawane sarwa roga winasaya, sarwa papa winasanem, sarwa klesa winasanam ya namo namah swaha (Raiyasa, wawancara 9 Oktober 2017). 
b Natab Banten Pakala-kalaan, tata cara pelaksanaan natab banten ini adalah dengan mempersilakan mempelai berdua untuk duduk menghadap Sanggah Kemulan, didahului dengan bersembahyang, kemudian diupakarai dengan sarana yang telah dipersiapkan separti: sisig, keramas, segau, dan tepung tawar selanjutnya diberikan penglukatan.

Adapun mantra natab banten pakala-kalaan adalah :

Om indah ta kita Sang Kala-Kali, puniki pabyakala-kalane si anu........katur ring Sang Kala-Kali Sadoyo, sira reka pakulun angelu waraken sakwehing Kala Kacarik, Kala Patti, Kala Karapan, Kala Karogan, Kala Mujar, Kala Kapepengan, Kala sepetan, Kala Kapepek, Kala Cangkingan, Kala Durbala-Durbali, Kala Brahma, makadi sakwehing Kala haneng ring wak sariranipun si anu.....sami pada kaluwarane de nira Bhatara Siwa wruh ya sira ring Hyang Hyangganing awak sarirania, kajenenganna denira Sang Hyang Tri Purusangkara, kasaksenan denira Sang Hyang Triodasasaksi, lah ya maruwaten Sang KalaKali mundura dulurane rahayu den nutugang tuwuh ipun si anu.....tunggunen dening bayu pramana, mwang wreddhi putra listu ayu (Raiyasa, wawancara 9 Oktober 2017).

Langkah selanjutnya kedua mempelai berjalan mengelilingi Sanggah Kemulan, Sanggah Pesaksi, tiap kali melewati Kala Sepetan kakinya disentuhkan sebagai simbul pembersihan sukla swanita dan dirinya. Setelah tiga kali kemudian pengantin yang laki berbelanja, sedangkan yang wanita menjual segala yang ada pada sok bebelanjan (sambil berjalan pengantin laki memikul tegen-tegenan, yang wanita munjunjung sok bebelanjan). Upacara jual beli ini sebagai simbol tercapainya kata sepakat untuk memperoleh keturunan. Kemudian dilanjutkan dengan merobek tikar (tikeh dadakan), dimana pengantin wanita memegang tikar dan pengantin pria merobek dengan keris yang berada pada penegtegan. Hal ini merupakan simbol pemecahan selaput gadis. Setelah itu kedua mempelai memutuskan benang yang terlentang pada cabang dapdap (pepegatan), sebagai tanda bahwa mereka telah melampaui masa remajanya, dan kini berada pada kehidupan baru sebagai pasangan suami istri. Selanjutnya bersama-sama mananam pohon kunir, andong dan keladi di belakang Sanggah Kemulan, dilanjutkan dengan mandi dan ganti pakaian, sesuai dengan dokumentasi peneliti yang diperoleh dilapangan.

c. Upacara masakapan di Bale. Upacara ini bersifat pengesahan secara niskala kedua mempelai. Pada saat ini dihadiri oleh prajuru adat, kelian banjar, dinas sebagai saksi sehingga perkawinan ini dianggap sah secara hukum agama dan hukum nasional, sehingga kedua mempelai sudah sebagai anggota pengayah ngarep (penuh) dalam masyarakat adat di Desa Pakraman Penataran.

d. Natab Banten Pejati

Natab banten pejati ini dilakukan setelah sebelumnya dilukat atau dibersihkan. Prosesi pelaksanaan natab banten pejati ini disertai dengan upacara mejaya-jaya dan natab banten dapetan. Upacara Mapejati ini bertujuan untuk menyatakan bahwa mulai saat itu si gadis tidak lagi menjadi tanggung jawab dan hak waris keluarganya melainkan tanggung jawab keluarga si pria. Rangkaian terakhir dari upacara perkawinan adalah upacara majauman, mapajati atau membawa tipat bantal. Upacara ini ditandai dengan membawa tipat bantal dengan segala 
kelengkapannya ke rumah mempalai wanita. Upacara ini bertujuan untuk mohon pamit secara sekala dan niskala oleh pihak mempelai wanita. Secara simbolik, upacara majauman ini adalah penyatuan dua unsur, yaitu penyatuan keluarga laki-laki dan keluarga dari pihak wanita. Dalam hal perkawinan dengan tradisi ngubeng karena tidak adanya kesepakatan atau persetujuan oleh pihak keluarga mempalai wanita, maka upacara mapamit bagi mempelai wanita dilaksanakan hanya dari sanggah kemulan mempelai pria yang mana upacara inilah disebut dengan ngubeng. Disinilah ciri khas dari pelaksanaan upacara perkawinan ngubeng itu tampak, karena si wanita tidak datang lagi ke rumahnya untuk mapamit secara niskala melainkan dibuatkan upacara mapamit di tempat suci mempelai laki-laki.

4 Ngandeg, yaitu memberitahukan kepada keluarga wanita bahwa anak gadisnya telah kawin, sebagai tanda bukti biasanya ada surat keterangan dari si wanita bahwa ia kawin berdasarkan saling mencintai, tanpa ada unsur paksaan (wawancara tanggal 9 Oktober 2017).

\subsection{Bentuk Upakara Perkawinan Ngubeng}

Upacara perkawinan yaitu merupakan persaksian kehadapan Ida Sang Hyang Widhi Wasa. Perkawinan merupakan pembersihan terhadap sukla swanita (benih) secara jasmani dan rohani. Agar bibit kedua mempelai bebas dari pengaruh-pengaruh buruk serta gangguan bhuta kala, sehingga kalau kedua bibit ini bertemu dan terjadi pembuahan maka terbentuklah manik yang sudah bersih.

Pelaksanaan suatu upacara perkawinan sudah tentu mempergunakan sarana yang berupa bebabtenan. Berdasarkan hasil wawancara dengan beberapa serati banten Desa Pakraman Penataran disebutkan beberapa sarana upakara yang dipergunakan pada pelaksanaan upacara perkawinan ngubeng adalah sebagai berikut :

1. Banten Pekala-kalaan yang terdiri dari : peras, ajuman, daksian, suci, tipat kelanan, sesayut, pengambyan, penyeneng, tulung, sanggah urip, pamugbug (tumpeng kecil 5 buah dialasi dengan kulit sesayut, raka-raka dan lauk- pauk), untek 7 buah (dialasi taledan dilengkapi dengan raka-raka dan lauk-pauk), solasan 22 tanding (nasi yang dialasi taledan kecil), bayuan (penek warna 5 dialasi daun telujungan, dagingnya olahan ayam brumbun, kemudian diatasnya ditaruh kulit ayam serta dilengkapi dengan kwangen), pabyakalaan, prayascita, lis, gelar sanga, tetabuhan, tikeh dadakan (sebuah tikar kecil yang dibuat dari daun pandan yang masih hijau), kala sepatan (sebuah bakul dari bambu yang berisi sebutir telur ayam mentah, ditutupi dengan sambuk belah tiga, diikat dengan benang tri datu, berisi cabang dapdap serta lidi masing-masing 3 biji), tengen-tengenan (terdiri dari cangkul, sebatang tebu, cabang dapdap. Diujungnya digantungi periuk yang berisi tutup dan diujung yang lain digantungi bakul berisi uang), sok pedagangan (sebuah bakul yang berisi beras, kain, bumbu-bumbuan, rempah-rempah,pohon kunir, keladi, andong serta kapas), penegtegan (biasanya dipakai tiang dari sanggah kemulan yang sebelah kanan, diisi sebilah keris lengkap dengan pakaiannya), pepegatan (dibuat dari dua buah cabang dapdap yang ditancapkan agak berjauhan dan keduanya dihubungkan dengan benang putih) dan tetimpug (dibuat dari potongan bambu yang masih kedua ruasnya, kemudian dibakar dan menghasilkan ledakan) (Wiani, wawancara tanggal 9 Oktober 2017).

2. Caru Patemon di jalan.

Caru ini biasanya dipergunakan atau ditempatkan di jalan, adapun sarana dari caru ini berisi nasi dialasi bakul, dagingnya karangan babi, nasi digulung 
dengan serabut pohon pinang (upih) dagingnya hati babi, dilengkapi dengan bunga cempaka, dua buah canang buratwangi, sesari 25 (selai) keteng dan tetabuhan. Caru ini dihaturkan kahadapan Sang Bhuta Hulu Lembu, Sang Bhuta Harta dan Sang Bhuta Kilang Kilung (Sunitri, wawancara tanggal 9 Oktober 2017).

3. Caru Patemon di pintu masuk rumah

Caru ini berisikan nasi takilan dengan dagingnya darah mentah, bawang, jahe, garam serta dialasi dengan tangkih. Caru ini dihaturkan kehadapan Sang Bhuta Pila-Pilu, Sang Hyang Sasarudira, Sang Hyang Muladrawa, Sang Hyang Ragapanguwus, Kaki Rangga Ulung dan Kaki Rangga Tan Kewuh (Wiani, wawancara tanggal 9 Oktober 2017).

\section{Banten Pejati/Jauman}

Banten ini berisi daksina, peras, ajuman, suci dengan daging itik guling, tipat kelanan, bantal, jaja kukus, dan beberapa jenis jajan lainnya, dilengkapi dengan sirih, pinang, gambir, tembakau, rantasan saparadeg (satu setel), dilengkapi dengan dua buah tumpeng lengkap dengan daging babi guling. Banten ini dihaturkan di Sanggah Kemulan. Kalau perkawinan secara umum banten jauman ini setelah di haturkan di Sanggah Kemulan keluarga si pria kemudian dibawa ke rumah si wanita, tetapi dalam upacara perkawinan ngubeng yang terjadi di Desa Pakraman Penataran, banten ini cukup dihaturkan di Sanggah Kemulan si pria saja dan mempelai wanita mepamit langsung dari sini, tanpa datang lagi ke rumahnya (Wiani, wawancara tanggal 9 Oktober 2017).

\section{PENUTUP}

Berdasarkan uraian di atas, maka dapat ditarik suatu simpulan sebagai berikut.

1. Perkawinan Ngubeng di Desa Pakraman Penataran dilakukan karena pihak perempuan tidak mendapat restu dari kedua orang tua, sehingga perkawinan tetap dilaksanakan dengan perwalian adat saja, serta pelaksanaan upacara yang biasa disebut mapamit (upacara permohonan diri untuk meninggalkan keluarga secara niskala) biasanya dilaksanakan dengan jalan mempelai laki-laki mengantar mempelai perempuan kerumahnya untuk mepamit. Karena perkawinan yang terjadi tidak mendapat restu dari keluarga perempuan, maka upacara mepamit bagi mempelai wanita yang semestinya dilakukan dengan datang ke rumah si wanita, cukup dilakukan pada Mrajan (Sanggah Kemulan) keluarga laki-laki.

2. Proses pelaksanaan Perkawinan Ngubeng di Desa Pakraman Penataran adalah sebagai berikut : 1) Mapadik, yaitu acara awal perkawinan dimana keluarga pihak laki-laki (purusa) mengambil inisiatif meminta si gadis, untuk dikawinkan dengan anak prianya. 2) Setelah mendapat jawaban disetujui atau tidak, seperti terjadinya perkawinan ngubeng yang sudah jelas tidak ada persetujuan dari pihak orang tua si gadis, maka tindakan yang dilakukan adalah melarikan anak gadisnya tanpa sepengetahuan orang tuanya. 3) Prosesi upacara yang dilaksanakan di rumah mempelai pria diantaranya natab banten byakala, pakala-kalaan, dan pejati 4). Ngandeg, yaitu memberitahukan kepada keluarga wanita bahwa anak gadisnya telah kawin, sebagai tanda bukti biasanya ada surat keterangan dari si wanita bahwa ia kawin berdasarkan saling mencintai, tanpa ada unsur paksaan. 


\section{DAFTAR PUSTAKA}

Arthayasa, dkk. 1998. Petunjuk Teknis Perkawinan Hindu, Surabaya : Paramita. 2004. Petunjuk Tehnis Perkawinan Hindu, Surabaya : Paramita

Badudu. J. S dan Mohamad Zein, 1994. Kamus Umum Bakasa Indonesia. Jakarta : Pustaka Sinar Harapan.

Gelgel, I Putu, 2006. Hukum Hindu, Denpasar : Rudita Karya

George Ritzer \& Duoglas J. Goodman, 2007. Teori Sosiologi Modern. Jakarta : Kencana.

Gulo, W. 2002. Metodelogi Penelitian. Jakarta : Grasindo.

Kajeng, I Nyoman, dkk. 2005. Sarasamuscaya dengan Teks Bahasa Sansekerta dan Jawa Kuno. Surabaya : Paramita.

Koentjaraningrat, 1979. Manusia dan Kebudayaan di Indonesia, Yogyakarta : Djambatan.

Kaler, I Gusti Ketut, t.t, Pawiwahan/Perkawinan Dalam Masyarakat Hindu di Bali.

Mantra, I.B. 1990. Bhagawadgita. Jakarta : Priyek Penggandaan Kitab Suci Hindu Departemen Agama RI.

Moleong, Lexy. J. 2002. "Metodologi Penelitian Kualitatif". Bandung : Remaja Rosdakarya.

Nasution, S. 1988. Metode Penelitian Naturalistik Kualitatif. Bandung : Tarsito.

Natih, I Ketut N, 1987. Sosiologi. Jakarta : Yayasan Wisma Karma

Nazir, Moh. 1988. Metode Penelitian. Jakarta : Ghalia Indonesia.

Pudja, G,1997. Bhagawad-Gita. Jakarta : Hanuman Sakti.

Pudja, Sudharta, 1995. Manawa Dharmaçastra, Jakarta : Hanuman Sakti.

Punyatmaja, I.B.Oka, 1976. Çilakrama. PHDI Pusat.

Rajin, I Ketut. 2007. Nilai-Nilai Pendidikan Agama Hindu Dalam Kehidupan Grahasta Asrama. Denpasar : Fakultas Ilmu Agama UNHI Denpasar.

Ridwan. 2004. “Metode dan Teknik Penyusunan Tesis”. Bandung : Alfa Beta Cetakan Pertama

Soelaeman, Munandar. 2000, Ilmu Sosial Dasar. Bandung : Refika Aditama

Sonhadji, 1994. Metodelogi Research. Jakarta : Balai Pustaka.

Suastawa, Darmayuda, 2001. Peranan Desa Pakraman Dalam Menyelesaikan Kasus Adat. Denpasar : Pemda. TK I Bali. 
Subagiasta, dkk, 1997. Modul Acara Agama Hindu. Jakarta : Direktorat Jendral Bimbingan Masyarakat Hindu dan Budha.

Sudijono, Anas. 2006. Pengantar Evaluasi Pendidikan. Jakarta : PT. Raja Grafindo Perkasa.

Suprayogo, Imam Dan Tabroni, 2001. Metodelogi Penelitian Agama Bandung : Rosdakarya.

Sutapa, I Ketut Agus, 2004. Penerapan Azas Monogami Bagi Umat Hindu di Desa Pangelipuran Setelah Berlakunya UU Perkawinan No. 1 Tahun 1974. Denpasar : Sekolah Tinggi Agama Hindu Negeri.

Tim Penyusun, 1990. Kamus Besar Bahasa Indonesia. Jakarta : Balai Pustaka , 1993. Kamus Bali-Indonesia. Denpasar : Dinas Pendidikan Dasar.

, t.t. Kamus Kawi-Indonesia. Denpasar : Dinas Pendidikan Dasar.

2000. Tuntunan Tugas-Tugas Prajuru Adat. Denpasar : Dinas Kebudayaan Propinsi Bali.

2003. Panca Yadnya. Pemerintah Kabupaten Tabanan

--, 2003. Perda. Propinsi Bali No.3 Tahun 2003 Tentang Perubahan Atas Perda. Prop.Bali No.3 Tahun 2001 Tentang Desa Pakram. Bali : Biro Hukum dan HAM Setda Propinsi Bali.

-, 2007. Vidya Duta. Denpasar : IHDN

, 2015, Susunan Prajuru Desa Pakraman Penataran. Tanpa Penerbit

, 2015, Profil Desa Mundeh Kauh. Tanpa Penerbit

Tusan, I Wayan 1985. Sarining Wariga. Tanpa Penerbit

Wira Adnyana, I Wayan. 2003. Upacara Perkawinan Memirak di Desa Adat Batur Kecamatan Kintamani Kabupaten Bangli. Skripsi. Denpasar : Fakultas Dharma Acarya IHDN

Yudiantara, I Made; dan Suantina I Made. 1996. Sosok dan Cara Kerja Penelitian Kualitatif. Denpasar : BK Fakultas Ilmu Sosial dan Ilmu Politik Universitas Warmadewa 